\title{
MORTALITY OF Frankliniella occidentalis (Pergande) (Thysanoptera: Thripidae) BY GAMMA IRRADIATION
}

\author{
Mortalidad de Frankliniella occidentalis (Pergande) (Thysanoptera: Thripidae) \\ con radiación gama
}

\author{
Jaime E. Araya ${ }^{1}$ *, Tomislav Curkovic ${ }^{1}$ y Herman Zárate ${ }^{2}$
}

\begin{abstract}
A B S T R A C T
The western flower thrips, Frankliniella occidentalis (Pergande), is a good working model for studies of irradiation as a quarantine treatment on agricultural products against this insect group. A study was conducted to evaluate the mortality of this species, resulting from different dosages of gamma irradiation. Field populations were collected and exposed to 0.5 , 1.0 , and $1.5 \mathrm{kGy}$ in a 60 -Cobalt irradiator. In a first experiment, 645 adult $F$. occidentalis per treatment were used. Adult mortality reached $35 \%$ to $67 \%$ after $1 \mathrm{~h}$ exposure, significantly higher than the control. In a second experiment with the same dosages and storage at $5-6^{\circ} \mathrm{C}$, evaluations were done at days 8 and 14 on at least 200 adults. Mortality increased significantly with the dosage of irradiation over time, and reached $95 \%$ with the higher dosage. In general, there were no differences between 8 and 14 days under cold storage for a given dosage. From a quarantine point of view, it is suggested to evaluate the combined effect of higher irradiation dosages and colder storage, as well as the effects of the treatments on fertility and fecundity of thrips.
\end{abstract}

Key words: Frankliniella occidentalis, gamma irradiation, quarantine treatment.

\section{R E S U M E N}

El trips de California, Frankliniella occidentalis (Pergande), es un buen modelo de trabajo en estudios del uso de la irradiación como tratamiento cuarentenario contra este grupo de insectos en productos hortofrutícolas. Se hizo un estudio para evaluar la mortalidad de varias dosis de radiación gama como tratamiento contra esta especie. Se colectaron muestras en el campo y se expusieron a 0,$5 ; 1,0$ y 1,5 kGy en un irradiador de Cobalto-60. En un primer experimento se utilizaron 645 adultos de F. occidentalis por tratamiento. Una hora después del tratamiento se obtuvo 35 a $67 \%$ de mortalidad, significativamente más que en el control. En un segundo experimento con las mismas dosis y almacenamiento a $5-6^{\circ} \mathrm{C}$, las evaluaciones se hicieron los días 8 y 14 sobre al menos 200 adultos. La mortalidad aumentó significativamente con la dosis de irradiación en el tiempo, y alcanzó a más de $95 \%$ con la dosis mayor. En general, no hubo diferencias entre los días 8 y 14 en almacenamiento en frío para una dosis determinada. Desde un punto de vista cuarentenario, se sugiere evaluar el efecto combinado de dosis mayores de irradiación y almacenamiento en niveles mayores de frío, así como los efectos de los tratamientos en la fertilidad y fecundidad de los trips.

Palabras clave: Frankliniella occidentalis, radiación gama, tratamiento cuarentenario.

\footnotetext{
${ }^{1}$ Universidad de Chile, Facultad de Ciencias Agronómicas, Casilla 1004, Santiago, Chile.

E-mail: jearaya@uchile.cl*Autor para correspondencia.

${ }^{2}$ Comisión Chilena de Energía Nuclear, Av. Nueva Bilbao 12.501, Las Condes, Santiago, Chile.

Recibido: 8 de marzo de 2006. Aceptado: 30 de junio de 2006.
} 


\section{INTRODUCTION}

According to Moy and Wong (2002), irradiation is a viable and economic option to treat fruit for export; decades of research have demonstrated its quarantine value in terms of efficiency, effectiveness, and product quality retention. However, although irradiation at a minimum absorbed dosage of $250 \mathrm{~Gy}$ has been approved by the USDA as a quarantine treatment for certain fruits in Hawaii to control tephritid flies, research must determine whether this dosage is sufficient against other quarantine pests such as thrips on commodities for export (Yalemar et al., 2001). The USDA proposed recently to allow irradiation on fresh agricultural imports from other countries (Hallman and Loharanu, 2002). A few papers have been published on the effects of irradiation on thrips (Dohino et al., 1996; Yalemar et al., 2001).

Several studies have been carried out in Chile on the effect of irradiation on shelf life of products which are normally affected by microorganisms (Urbain, 1986; Rubio, 1989). However, comparatively little has been studied on its effect as a pest control method. For example, Sazo and Gerstle (1989) studied irradiation treatments on two quarantine pests on fruit for export, the weevil Naupactus xanthographus Germar (Coleoptera: Curculionidae), and the false grape mite Brevipalpus chilensis Baker (Acarina: Tenuipalpidae). Jadue et al. (1997) studied radiation effect on B. chilensis. The potential use of irradiation as a quarantine treatment in diverse agricultural products has been presented by Mangan and Sharp (1994) and Bakri et al. (2005).

The western flower thrips, Frankliniella occidentalis (Pergande), is an important pest of many crops in Chile (Quiroz et al., 2005). A closely related species, $F$. australis Morgan ( $=$ F. cestrum Moulton) is a native species with quarantine status for several countries, responsible for many rejections during preshipment inspections of export fruit (ASOEX, 2004), and for which no quarantine treatment has been developed. Mortality is a criterion of quarantine security used traditionally during inspections, as sterility is not possible to verify rapidly. An important issue in the area of irradiation as quarantine treatment is the difficulty for inspectors to accept insect samples surviving irradiation but sterilized by this process. Because of this, countries are still discussing the protocols to implement this technique as a method acceptable to all concerned parties, and yet, there are few accepted commercial applications, such as insect pests in Mangifera indica L., a species of mango from Hawaii (Moy and Wong, 2002).
Based on the preliminary studies in Chile by Sazo and Gerstle (1989), Rubio (1989) and Jadue et al. (1997), this new study was conducted to evaluate the effect of irradiation on mortality of $F$. occidentalis. Although not being a quarantine pest, this species constitutes a good working model for studies with thrips on agriculture products, since according to Bakri et al. (2005), generic dosages of irradiation apply to species within the same genus.

\section{MATERIALS AND METHODS}

Trips collecting. Starting in December 2004, flowers of several weeds, mostly Brassica rapa L., Galega officinalis L., Cichorium intybus L., in a field at the Campus Antumapu, College of Agriculture, University of Chile, Santiago, were examined to collect western flower thrips. These flowers were shaken firmly several times onto white trays, early in the morning (08:00-09:00 h), and the thrips loosened were collected quickly using hand aspirators and kept in cold temperature $\left(6-8^{\circ} \mathrm{C}\right)$ in $100 \mathrm{~mL}$ plastic vials.

Determining irradiation time. Experiments were carried out in the Department of Nuclear Applications at the Comisión Chilena de Energía Nuclear (CCHEN), using an experimental irradiator (Gammacell $220 \mathrm{R}$, MDS Nordion, Ottawa, ON, Canada), which emits gamma ray from a 60 -Cobalt source at a nominal activity of $160.802 \mathrm{GBq}$ (4.346 Curie), measured in January 2005. The irradiator had a 2 L cylindric chamber $(18 \mathrm{~cm}$ high $\times 13 \mathrm{~cm}$ diameter $)$ to treat samples. Yellow Perspex polymethylmethacrylate ASTM E1276-96 dosimeters (Southampton, UK) were used to estimate the irradiation time for $0.5 ; 1.0$ and $1.5 \mathrm{kGy}$. Vials with thrips were placed on a piece of expanded polystyrene of average density to get a uniform irradiation dosage. The dosimeters exposed were read with a spectrophotometer (Perkin Elmer Lambda 4, Norwalk, Connecticut, USA) at $531 \mathrm{\eta m}$. Absorbed dosages in the treatment area for 0.5, 1.0, and $1.5 \mathrm{kGy}$ ranged from 0.38 to 0.66 ; 0.76 to 1.32 ; and 1.14 to $1.98 \mathrm{kGy}$, respectively. The average dosage uniformity was estimated as 1.29 , whereas the dosage

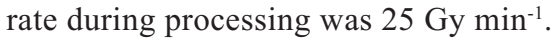

Irradiation experiments. Two experiments were conducted. In the first, an average 645 adult western flower thrips per treatment were used. Preliminary evaluations indicated that it was possible to maintain and manipulate these thrips without significant mortality in the control $(<5 \%)$. The specimens collected were taken within $1 \mathrm{~h}$ to the CCHEN laboratory, where they were treated immediately with $0.5,1.0$ or $1.5 \mathrm{kGy}$, leaving an untreated control. 
In Experiment 2, the cumulative effect of the same irradiation dosages was evaluated at days 8 and 14 of cold storage. This, to simulate storage and/or shipment conditions during export of fruit that may be infested with thrips (however, the equipment used reduced temperature to $5-6^{\circ} \mathrm{C}$ only). Irradiation exposure of at least $200 \mathrm{~F}$. occidentalis adults per treatment was conducted under the same conditions described for experiment 1 . Flower buds were added to the vials for the thrips to feed during cold storage.

Mortality symptoms and evaluations. Mortality was evaluated at 20X magnification $1 \mathrm{~h}$ after treatment in Experiment 1, and at days 8 and 14 in Experiment 2. The $1 \mathrm{~h}$ evaluation was the minimal time after treatment for insect counting, plus the fact that it is important to evaluate the effects of irradiation as soon as possible because some high priced products are exported quickly by air. Thrips were considered dead when they did not react when touched with a camel hair, even though at the $1 \mathrm{~h}$ evaluation (Experiment 1) many of them appeared plump, with no other symptoms. Some dehydration was observed, however, on treated thrips at the 8 and $14 \mathrm{~d}$ evaluations in Experiment 2. At the $8 \mathrm{~d}$ evaluation, most thrips alive were inside the flower corollas and were dislodged by shaking them, collected immediately with an aspirator, and returned to the vial with new insectfree flowers, where they were kept until the second evaluation.

Experimental design and data analysis. A completely randomized design was used, with four replicates per treatment. Each replicate was exposed separately to irradiation. About 160 and 50 adults per replicate were used in Experiments 1 and 2, respectively. Results of percentage mortality were normalized by transformation to Bliss $(\arcsin \sqrt{ } \%$ mortality) and subjected to ANOVA. Means were separated statistically by Tukey tests. The Chi-square test was used to verify independence when comparing dates of evaluation ( 8 vs. $14 \mathrm{~d}$ after irradiation) in each treatment $(\mathrm{P}=0.05)(\mathrm{Zar}, 1996)$. $\mathrm{P}$ values were estimated from the $\chi^{2}$ table at the The Bioactive Site (2006) web page.

\section{RESULTS AND DISCUSSION}

Experiment 1. Adult mortality obtained was $c a$. 35$67 \%$, significantly higher than in the untreated control, but no differences were observed among the dosages applied (Table 1). Thrips irradiated did not present evident symptoms of exposure, differently to the individuals of $B$. chilensis treated by Jadue et al. (1997), which resulted depigmented clearly. These
Table 1. Mortality of Frankliniella occidentalis measured $1 \mathrm{~h}$ after irradiation.

Cuadro 1. Mortalidad de Frankliniella occidentalis 1 h después de la irradiación.

\begin{tabular}{cc}
\hline Treatments (kGy) & Mortality (\%) \\
\hline 1.5 & $35.21 \mathrm{~b}$ \\
1.0 & $67.46 \mathrm{~b}$ \\
0.5 & $44.72 \mathrm{~b}$ \\
0.0 & $5.54 \mathrm{a}$ \\
F ANOVA & 10.26 \\
Probability & $<0.001$ \\
\hline
\end{tabular}

Means in a column with the same letter are not significantly different according to Tukey's test $(\mathrm{P}=0.05)$.

results indicate that $1 \mathrm{~h}$ after irradiation at the evaluated dosages, an important effect of rapid but not total mortality occurs. However, these dosages should be evaluated further to verify their effect on insect sterility.

Considering the probable presence of adults and nymphal stages together, these results could be higher on mixed populations, as irradiation effects are higher in initial stages undergoing active cell division. According to the International Consultative Group on Food Irradiation (ICGFI, 1991), irradiation at sublethal dosages might even prevent reproduction, although we did not measure either fecundity or fertility. In the study of Yalemar et al. (2001) with $F$. schultzei (Trybom), irradiation at 250 Gy caused failure of larval development and sterility of adults; expression of mortality was directly related with time elapsed from exposure to irradiation.

Experiment 2. Mortality at days 8 and 14 increased significantly with the dosage of irradiation, and reached more than $95 \%$ with the higher dosage (Table 2 ). Mortality was not significantly different between 8 and $14 \mathrm{~d}$ after irradiation (except for the $1.0 \mathrm{kGy}$ dosage); the $\chi^{2}$ values and their respective probabilities for $0.0,0.5,1.0$, and $1.5 \mathrm{kGy}$ were 1.1 $(\mathrm{P} \approx 0.31), 0.2(\mathrm{P} \approx 0.72), 4.1(\mathrm{P} \approx 0.04)$, and $0.1(\mathrm{P} \approx$ $0.75)$, which indicates a general independence between the evaluation dates and the level of mortality. A few thrips not exposed to irradiation survived more than 3 wk in the control under refrigeration, during which they kept feeding on the alfalfa (Medicago sativa $\mathrm{L}$.) floral buds.

As in other studies on effects of irradiation on arthropods (Sazo and Gerstle, 1989; Jadue et al., 1997), mortality was directly related to the dosage applied. Significantly more thrips exposed to the 
Table 2. Cumulative mortality of Frankliniella occidentalis at days 8 and 14 after irradiation.

Cuadro 2. Mortalidad acumulada de Frankliniella occidentalis los días 8 y 14 después de la irradiación.

\begin{tabular}{ccc}
\hline $\begin{array}{c}\text { Treatments } \\
(\mathbf{k G y})\end{array}$ & $\begin{array}{c}\text { Mortality } \\
(\mathbf{\%}) \mathbf{a t} \mathbf{8} \mathbf{d}\end{array}$ & $\begin{array}{c}\text { Mortality } \\
(\mathbf{\%}) \text { at } \mathbf{1 4} \mathbf{~ d}\end{array}$ \\
\hline 1.5 & $95.00 \mathrm{Ad}$ & $95.80 \mathrm{Ac}$ \\
1.0 & $67.00 \mathrm{Ac}$ & $79.60 \mathrm{Bb}$ \\
0.5 & $24.00 \mathrm{Ab}$ & $26.50 \mathrm{Aa}$ \\
0.0 & $10.10 \mathrm{Aa}$ & $14.90 \mathrm{Aa}$ \\
F ANOVA & 130.05 & 99.86 \\
Probability & $<0.000$ & $<0.000$ \\
\hline
\end{tabular}

Means in a column with the same small letter, and in a row with the same capital letter, are not significantly different according to Tukey (columns) and chi-square (rows) tests $(\mathrm{P}=0.05)$.

higher dosage (1.5 kGy) than to the medium (1.0 kGy) and the lowest $(0.5 \mathrm{kGy})$ dosages died after $14 \mathrm{~d}$ of cold storage at $5-6^{\circ} \mathrm{C}$. Similarly, Jadue and Vargas (1994) found also a synergistic effect between irradiation (up to $1.5 \mathrm{kGy}$ ) and $15 \mathrm{~d}$ cold storage at 0 $2^{\circ} \mathrm{C}$ for B. chilensis.

The lower levels of mortality in Experiment 2 with $0.5 \mathrm{kGy}$, as compared with Experiment 1 could be due, in part, to the fact that population samples at the second test were fed with alfalfa floral buds, although the increased time may have also allowed a later expression of mortality, as indicated for sub-lethal dosages of irradiation by Yalemar et al. (2001) for $F$. schultzei. Due to the feeding provided in Experiment 2 , the results from both experiments should not be compared.

The survival at $8 \mathrm{~d}$ and particularly at $14 \mathrm{~d}$ with $F$. occidentalis do question the viability of using irradiation against either this species or F. australis, a quarantine species restricted in foreign markets. New studies have to test lower commercial temperature storage conditions than those used here, plus irradiation, considering that the combined effect of different control factors could achieve better results (Mangan and Sharp, 1994).

\section{CONCLUSIONS}

At $1 \mathrm{~h}$ after irradiation no differences were observed in adult trips mortality (levels were lower than 68\%) between $0.5,1.0$ and $1.5 \mathrm{kGy}$, although all dosages showed higher mortality than control $(5.54 \%)$. However, the survival level of irradiated trips questions the viability of these dosages as quarantine treatments. On the other hand, differences occurred when evaluations were conducted 8 and 14 days after irradiation and cold storage $\left(5-6^{\circ} \mathrm{C}\right)$, where mortality was directly proportional to dosage. Further studies should combine the use of commercial cold storage plus irradiation on trips mortality, fecundity, and fertility.

\section{LITERATURA CITADA}

ASOEX. 2004. Informe del programa de preinspección. Temporada 2003-2004. Circular 007/2004. 11 p. [in Spanish]. Asociación de Exportadores de Chile (ASOEX), Santiago, Chile.

Bakri, A., N. Heather, J. Hendrichs, and I. Ferris. 2005. Fifty years of radiation biology in entomology: Lessons learned from IDIDAS. Ann. Entomol. Soc. Am. 98:1-12.

Dohino, T., K. Tanabe, S. Masaki, and T. Hayashi. 1996. Effects of electron beam irradiation on Thrips palmi Karny and Thrips tabaci Lindeman (Thysanoptera: Thripidae). Research Bulletin of the Plant Protection Service (Japan) 32:23-29.

Hallman, G.J., and P. Loharanu. 2002. Generic ionizing radiation quarantine treatments against fruit flies (Diptera: Tephritidae) proposed. J. Econ. Entomol. 95:893-901.
ICGFI. 1991. Code of food irradiation practice for food disinfestations of fresh fruits (as a quarantine treatment). Doc. 7. 13 p. International Consultative Group on Food Irradiation (ICGFI), Vienna, Austria.

Jadue, Y., y C. Vargas. 1994. Evaluación de la radiación ionizante como tratamiento de control cuarentenario de la falsa arañita de la vid (Brevipalpus chilensis Baker) [in Spanish.]. 139 p. Tesis Ingeniero Agrónomo. Universidad de Chile, Facultad de Ciencias Agrarias y Forestales, Santiago, Chile.

Jadue, Y., C. Vargas, J.E. Araya, and T. Rubio. 1997. Preliminary evaluation of ionizing radiation as a quarantine treatment for the false grape mite, Brevipalpus chilensis. Z. Pflanzenkrankh. Pflanzenschutz. 104:222-230. 
Mangan, R.L., and J.L. Sharp. 1994. Combination and multiple treatments. Chapter 16. p. 239-247. In Sharp, J.L., and G.J. Hallman (eds.). Quarantine treatments for pests of food plants. Westview Press, Boulder, Colorado, USA.

Moy, J.H., and L. Wong. 2002. The efficacy and progress in using radiation as a quarantine treatment of tropical fruits: a case study in Hawaii. Radiat. Phys. Chem. 63:397-401.

Quiroz, C., P. Larraín, y P. Sepúlveda. 2005. Abundancia estacional de insectos vectores de virosis en dos ecosistemas de pimiento (Capsicum annum L.) de la Región de Coquimbo, Chile. [in Spanish.]. Agric. Téc. (Chile) 65:3-19.

Rubio, T.C. 1989. Effect of low dosages ( $<1 \mathrm{kGy})$ in the commercial quality of fresh fruits and vegetables for export. Food Irradiation Newsl. 13(2):26-27.
Sazo, L., y C. Gerstle. 1989. Efecto de las radiaciones de Cesio 137 sobre la mortalidad de Naupactus xanthographus Germar (Coleoptera: Curculionidae) y Brevipalpus chilensis Baker (Acari: Tenuipalpidae). [in Spanish.]. Cien. Inv. Agr. 16:65-67.

The Bioactive Site. 2006. Chi-square to P-value conversion table. Available at http://www. rickhershberger.com/bioactivesite/bio318/chi-toP.htm Accessed Aug. 8, 2006.

Urbain, W.M. 1986. Food irradiation. 351 p. Academic Press, Orlando, Florida, USA.

Yalemar, J.A., A.H. Hara, S.H. Saul, E.B. Jang, and J.H. Moy. 2001. Effects of gamma irradiation on the life stages of yellow flower thrips, Frankliniella schultzei (Trybom) (Thysanoptera: Thripidae). Ann. Appl. Biol. 138:263-268.

Zar, J. 1996. Biostatistical analysis. 620 p. Prentice Hall, Upper Saddle River, New Jersey, USA. 